\title{
Fanconi Anemia, Complementation Group D1
}

National Cancer Institute

\section{Source}

National Cancer Institute. Fanconi Anemia, Complementation Group D1. NCI Thesaurus.

Code C125705.

Fanconi anemia caused by mutations of the BRCA2 gene. 